\title{
THE IMPACT OF POPULATION PROCESSES ON ADULT TRAINING IN BORSOD-ABAÚJ-ZEMPLÉN COUNTY BETWEEN 2010 AND 2019
}

\author{
Dávid Hajdú \\ PhD student \\ Hungarian University of Agriculture and Life Sciences, Doctoral School of Economy and \\ Regional Sciences \\ E-mail: hajdu.david91@gmail.com
}

\begin{abstract}
The study examines the population processes of Borsod-Abaúj-Zemplén County and the correlations of the participants in adult training between 2010 and 2019. The County's resident population is steadily declining, with the decline exceeding 110,000 over the past 20 years. The number of deaths each year exceeded the number of live births. The County has a slow process of depopulation and is characterized by aging. The county is characterized by significant migration losses, due to high unemployment and a relatively low employment rate. The solution to reducing unemployment can be adult training, which can respond quickly to changes in the labor market, thus reducing the emigration caused by unemployment. Research seeks to answer the question of how declining resident population affects participation in adult training.
\end{abstract}

Kulcsszavak: population processes, adult training, disadvantage, emigration JEL besorolás: I26, J24, M53

LCC: HD5701-6000.9

\section{Introduction}

Demographic processes show very well-studied differences at different territorial levels, which thus have an impact on economic development, but also summarize well the effects of persistent favorable or unfavorable development trends. At the settlement level, the socialist industrial cities and mining settlements that have been declining in recent decades can provide a negative example of this in the Region (Gubacsi, 2017). The most positive phenomena were observed and the suburban municipalities that have been close to the larger cities, human resource replenishment (Szücs, 2014).

The appearance of territorial differences can be considered a natural corollary of development processes. With the accumulation of socio-economic advantages and disadvantages, different levels of centers and peripheries are fixed in space. Differences between these can be reduced through social interventions, which is a fundamental objective of regional policy (Enyedi, 1996; Kiss-Németh, 2006; Faragó, 2016). The focus of the research is on the delimitation of development centers and axes, as well as on the delimitation of disadvantaged settlements and areas from the point of view of territorial policy (Matolcsy - Csizmadia - Csordás, 2007; Nagy et al., 2015; Pénzes, 2015).

Measuring the territorial differences of the country can be considered as a thoroughly researched topic, based on both more general socio-economic aspects and aspects of individual narrower fields (Nemes-Nagy, 2004; Obádovics-Bruder 2011). Economic and social differences in the regional approach can be examined partly on the basis of the range of data available at the settlement level, but still on the basis of several aspects. Researchers in regional 
science compile complex indicators based on various aspects from the available data in order to more accurately describe developmental processes (Dunnell, 2009; Lipták 2017).

The development of centers that accommodate spectacular investments in Hungary is fundamentally influenced by the availability of resources (internal) and the ability to attract them (external). Foreign-invested capital investment also favors larger cities where adequate accumulation of human capital has been or can be achieved in the near future. After all, the basis of these investments is the availability of the right workforce. The shortage of skilled labor is a growing problem across Central Europe. And in the future, with the development of the knowledge-based society, the importance of human capital will only increase (Lux, 2017).

The analysis of population processes, the exploration of the causes of changes, the connection of demographic phenomena with the fields of economics - labor market, spatiality, economic development - are essential in order to draw well-founded conclusions. All this presupposes that from time to time we stop, look back, evaluate the processes that took place over time, and shed light on the changes and the deeper causal relationships behind the phenomena (Koncz et al., 2018).

The primary subject of traditional demography is four phenomena: fertility, mortality, international migration, internal migration (Kapitány et al., 2015). In my study, fertility and internal migration were highlighted, which is due to the fact that the most significant changes took place here in Borsod-Abaúj-Zemplén County during the study period.

The concept of internal migration is closely linked to the concept of natural and actual reproduction. Natural weight loss results from death in excess of live births, while actual weight loss takes into account the difference between domestic and foreign migration in addition to births and deaths. However, the comparison of the two concepts is not only methodologically important, but also in terms of its impact and intensity influencing economic and social processes. Births and deaths have a slow, gradual effect, while migration can change the number and structure of the population in a relatively short period of time (Földvári, 2014).

Since the change of regime, market participants have increasingly turned to the research and training market (Rédei, 2006), in parallel with the decline in public funding for training, which has included the analysis of the educational characteristics of demography in a completely different aspect. The increasingly complex nature of economic and social processes has also expanded the methodology used by demography. In recent decades, empirical research and the methods for analyzing have become more prominent.

The main motives for internal migration are primarily economic, of which the labor market plays a significant role (Bába, 2008). Due to the expanding job opportunities, cross-border emigration from rural settlements is also increasing. The pattern of migration and mobility is different in the case of the unemployed, those with a university degree, those living in the County seat (Gödri - Feleky, 2013) and, we assume, also those living in peripheral areas.

In the counties of the Northern Hungary region, the dominant demand in the labor market has been the industry for more than 40 years. The number of commuters from geographically peripheral areas to industrial centers has been steadily increasing in the region. By the end of the $1970 \mathrm{~s}$, more than half $(51.8 \%)$ of the large-scale industrial workers in Borsod-AbaújZemplén County worked in the heavy industry sector (Dabasi-Halász - Hegyi-Kéri, 2015). 
The close link between economic performance and education has also been recognized by the government and has launched catch-up programs for disadvantaged children, which generally provide financial and learning support for students (Rajnai, 2012). The objectionability of the education system has created catching-up programs, as family disadvantages are not reduced but conserved by the Hungarian education system (Csapó et al., 2009). Parents of a disadvantaged child have limited financial means, usually no educational experience, and as a result enroll their child in the nearest school (Sucharita, 2014).

Marginalized groups face skills disadvantages that prevent them from stabilizing their position in the labor market. Unemployment has become a way of life in the lives of the unemployed, the unskilled or otherwise disadvantaged, to the detriment of their children, i.e. the next generations as well. Although adult training is not a direct solution to the problems caused by exclusion, poverty, it can lead to the reduction of these conflicts (Hangya, 2013). Adult training is a key factor in combating social and labor market discrimination (Farkas, 2013; Hangya, 2013). The issue of equal opportunities and equity must be a priority in modern and innovative education policy. Today, training is not only a national but also a global issue, it can be considered a factor of competitiveness of the European Union member states (Hangya, 2013).

Access to education is unequal due to the type of residence and geographical location, as a disadvantaged individual living in a city has a much better chance than living in a peripheral village. Of course, this is also true at the regional level, it does not matter whether someone lives in the north-west of the country or in the north-east (Híves, 2015). Often, huge differences can also be detected between schools located within a settlement, i.e., territorial inequality can be detected at all territorial levels and in all forms of education (Rolleston-James, 2015). The expansion of competencies is closely related to the accelerating changes in labor market needs. There is a very close relationship between unemployment, employment and basic skills (Farkas, 2013; Győri - Járdány, 2019). In the field of preferred competencies in the labor market, a similar difference can generally be detected between the above and lagging regions as in the case of qualification levels, with the proviso that outside some schools there is not as much difference in competences that can be acquired in "real life". It is more pronounced in the case of foreign language skills (Tésits - Alpek, 2013).

\section{Material and method}

As a basis for the secondary research, I reviewed the available domestic and international textbooks and journal articles on the topic. After getting to know them, I studied and downloaded the data of the Hunrgarian Central Statistical Office, National Employment Service and the databases available on the OSAP 1665 Statistical Interface. The analysis was performed on the population processes of Borsod-Abaúj-Zemplén County and on the participants in adult training. The research covers the last 10 years. For the spatial analysis of the calculated statistical data and for the mapping of the obtained results ArcGIS 10.6.1. I used GIS software. Time series analyzes were performed using Micrfosoft Excel.

To examine the spatial dimensions of the square value of the proportion of participants in adult training (2010 and 2019) per settlement, I used a spatial autocorrelation study. I used Local Moran I statistics to detect similar spaces. Given the high number of neighborhood degrees, I chose a "queen contiguity" conceptualization for the spatial weight matrix. I set the permutation level to 499. The significance level was determined at $\mathrm{p}<0.10$.

For 2010 and 2019, I calculated the ratio of the number of participants in adult training to the number of resident population, and aggregated the result at the LAU 2 level. To examine the 
aggregates from a territorial point of view, I performed a Hotspot analysis based on General G statistics. For the analysis I used a "queen contiguity" weight matrix, for which the significance level was determined at $\mathrm{p}<0.05$.

Based on the examination of the socio-economic indicators of the county, in recent years there has been a catching up and a decreasing backlog from the national averages. At the same time, districts within the County are characterized by different economic and social data. Within the County, the areas that have started to catch up can be well distinguished from those that can be classified as permanently depressed (Koncz et al., 2018). I put this County at the center of my study because it was characterized by a persistently high unemployment rate and high participation in training over the time interval of the research. There are 16 districts in BorsodAbaúj-Zemplén County with different unemployment and economic situations. Based on its socio-economic indicators, the district of Miskolc stands out in a positive direction, which is of course due to the dominant role of the city with County status (Koncz et al., 2018).

Among the rural districts of Borsod-Abaúj-Zemplén County, those with a stable industrial center are in a better position, however, only the districts of Miskolc and Tiszaújváros do not count as beneficiary districts in any respect 290/2014 on the classification of beneficiary districts. Based on a government decree. Thus, the implementation of the objectives of territorial equalization and catching up, ie cohesion, is a particularly important task in the County. Adult training can play an important role in this. training is the only form of education that is able to react the fastest to changes in the labor market, so it can reduce and slow down the emigration caused by unemployment.

\section{Results}

Borsod-Abaúj-Zemplén County has experienced a drastic decrease in its resident population in the last 10 years (Figure 1). The negative change is due to the aging of the County, emigration from the County and the declining number of live births. During the period under review, the population of the County decreased by more than 49 thousand people, which is $7.11 \%$ of the population in 2010, which corresponds to the current population of the two largest district centers of the County.

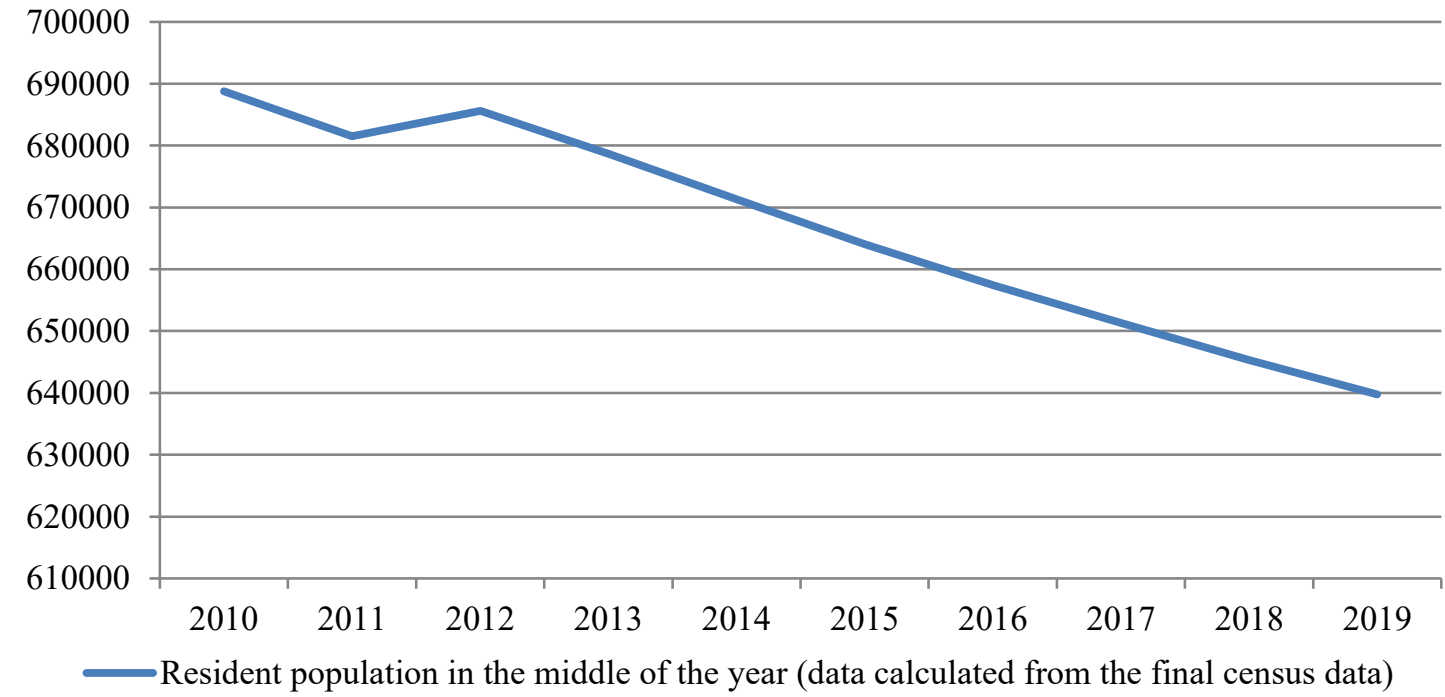

Figure 1: Change of the resident population in Borsod-Abaúj-Zemplén County (20102019) (persons)

Source: Based on the data of my own creation (www.ksh.hu) 
The number of live births did not exceed the number of deaths in any of the years under study, which also shows that the County is struggling with aging. The biggest difference was in 2010, when the number of deaths exceeded the number of live births by 3,191 . On average over the past 10 years, $27.5 \%$ more people die than are born (Figure 2 ).

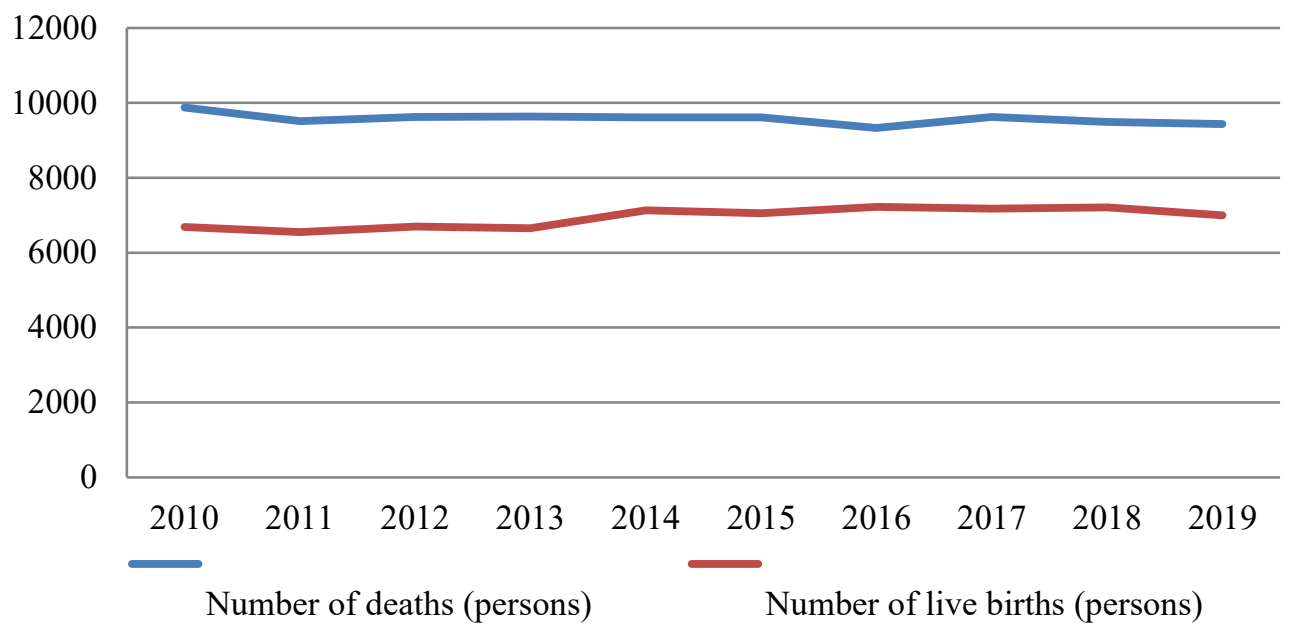

Figure 2: Number of deaths and live births in Borsod-Abaúj-Zemplén County (20102019)

Source: Based on the data of my own creation (www.ksh.hu)

For the past 18 years, emigration has been dominant in the County. Most migrants were in 2019 and the fewest migrants were in 2013. Examining the migration balance over time, we can state that it reached its maximum in 2007 (19\%) and its minimum in $2002(12.6 \%)$. The average migration balance of the studied period was $-15.6 \%$, due to which the population of the County is drastically decreasing from year to year.

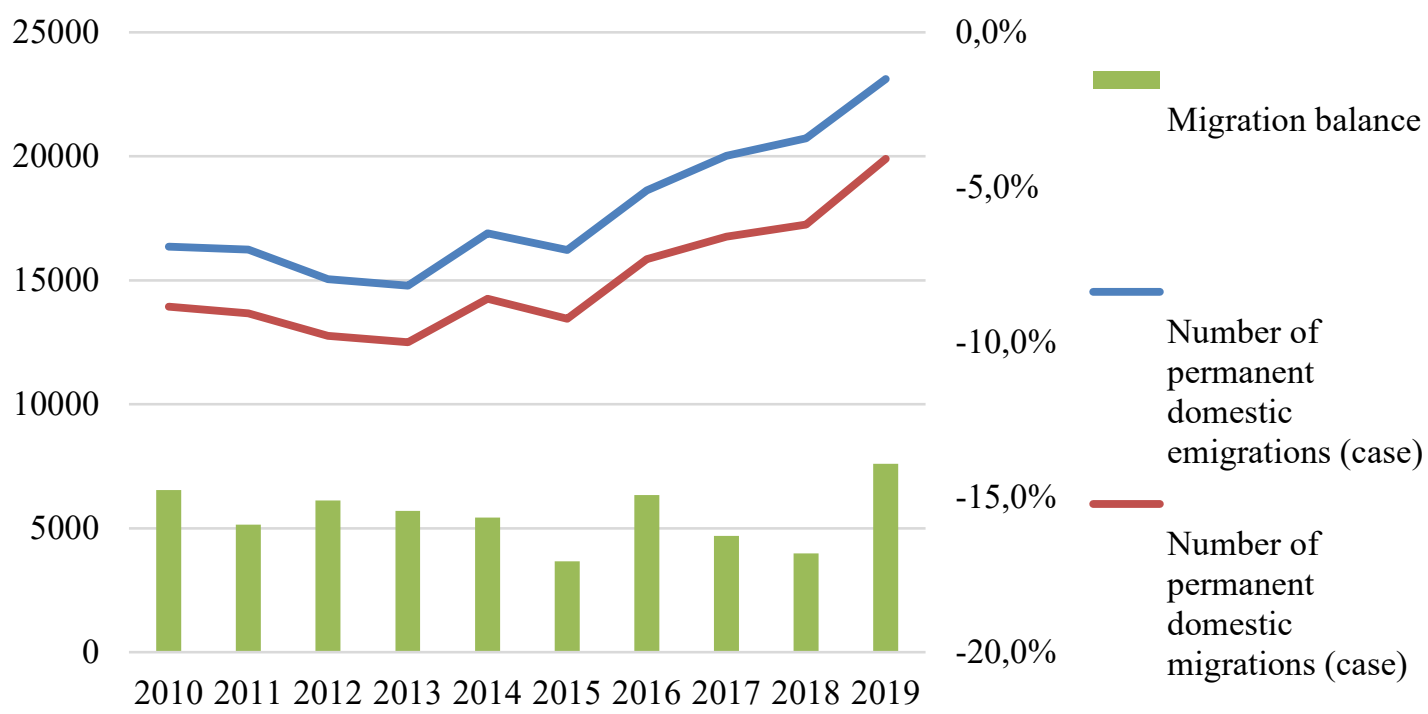

Figure 3: Development of migration balance in B-A-Z County (2010-2019)

Source: Based on the data of my own creation (www.ksh.hu)

Borsod-Abaúj-Zemplén County, with the exception of the capital, has the second largest number of participants in terms of adult training. By gender, the proportion of women in BAZ County is higher than in any NUTS 3 region in the country. The ratio of participants in adult training to the total resident population is steadily increasing. The highest ratio occurred in 
2018, while the lowest occurred in 2016. The decline was due to the closure of the application rounds. The majority of participants in adult training in the County $(89.1 \%)$ participate in free education, ie the willingness to pay for education is low. The trainings financed by the European Union and the state apply to disadvantaged regions, including the County. Figure 4 also illustrates well that in the last 2 years more than $10 \%$ of the County's resident population has participated in adult training.

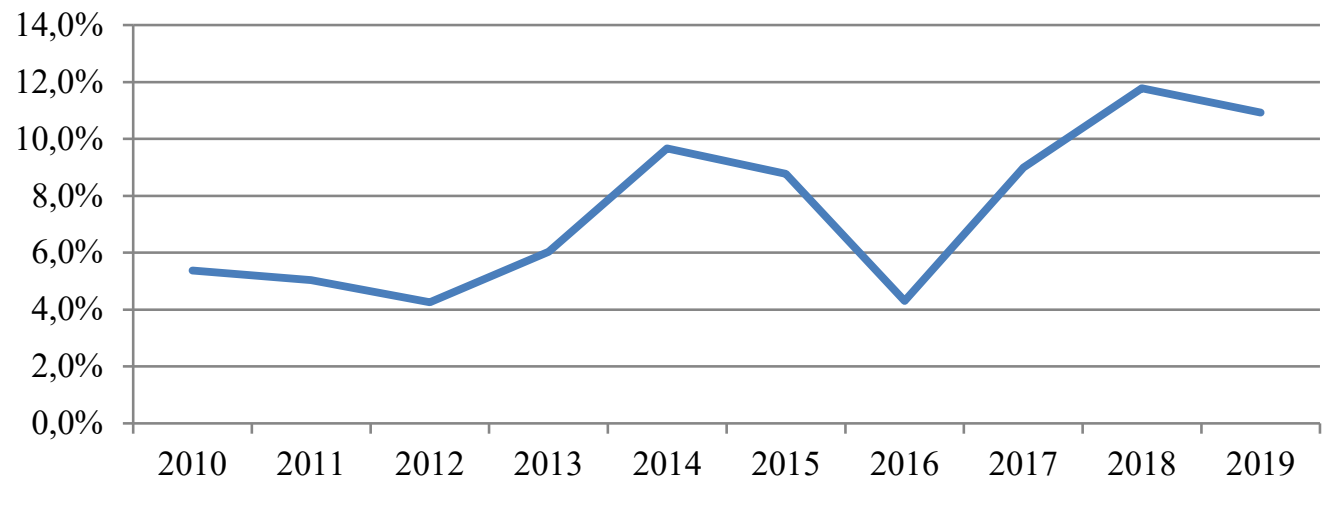

Proportion of participants in adult training in relation to the total resident population

\section{Figure 4: Proportion of participants in adult training in relation to the total resident population of B-A-Z County (2010-2019)}

Source: Based on own data (www.osap.mer.gov.hu; www.ksh.hu)

In the baseline ratio study, I considered 2010 as the base and, as a result, examined the next nine years. During the study, the resident population shows a continuous linear decline over the observed period. The change in the number of participants in adult training compared to the resident population shows a rather hectic picture. The proportion of participants in adult training has doubled in the last 10 years. The biggest decline was in 2016. Figure 5 also perfectly illustrates that the resident population does not influence the proportion of participants in training, because the declining trend of the resident population did not affect the increasing direction of adult training in each year examined.

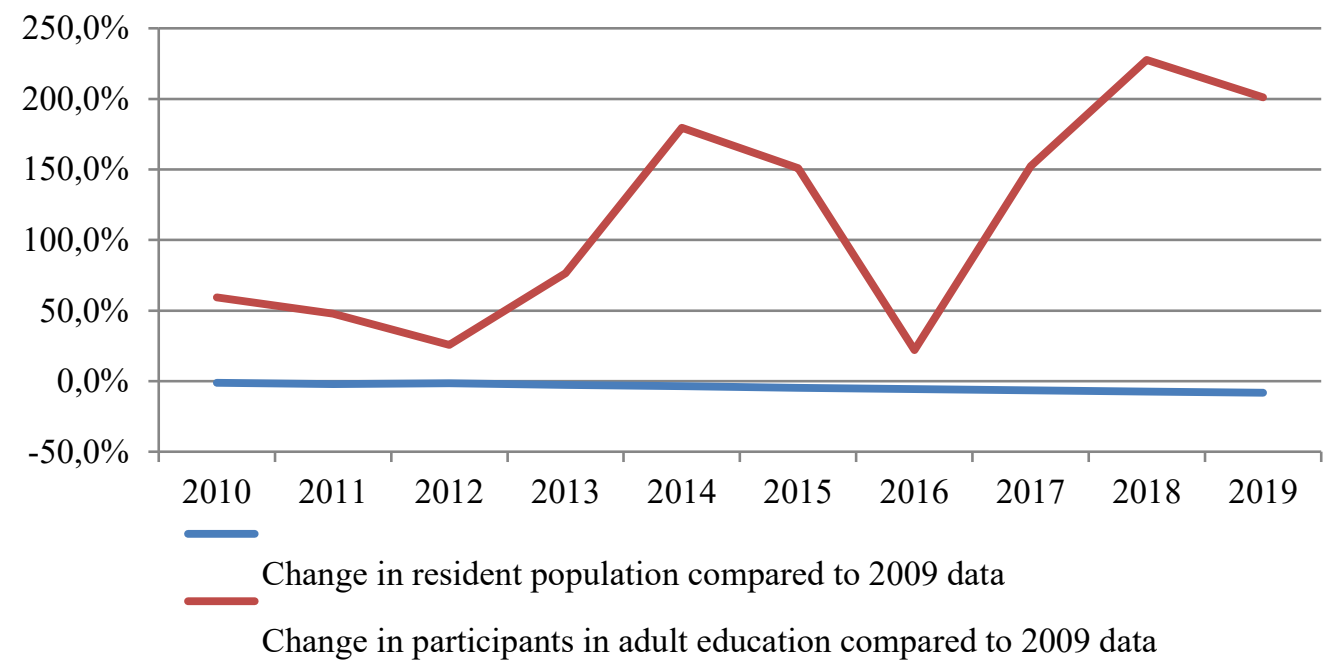

Figure 5: Change in the resident population and participants in adult training compared to 2009 data (2009-2019)

Source: Based on own data (www.osap.mer.gov.hu; www.ksh.hu) 
In Borsod-Abaúj-Zemplén County, the number of unemployed shows a continuous decreasing trend. Most job seekers were in 2011, the fewest in 2018. For absolute jobseekers, emigration has a positive effect, as the number of unemployed decreased during the period under review. The proportion of jobseekers relative to the resident population is also declining year by year, due to emigration, aging, public employment and multinational companies involved in the region (Figure 6).

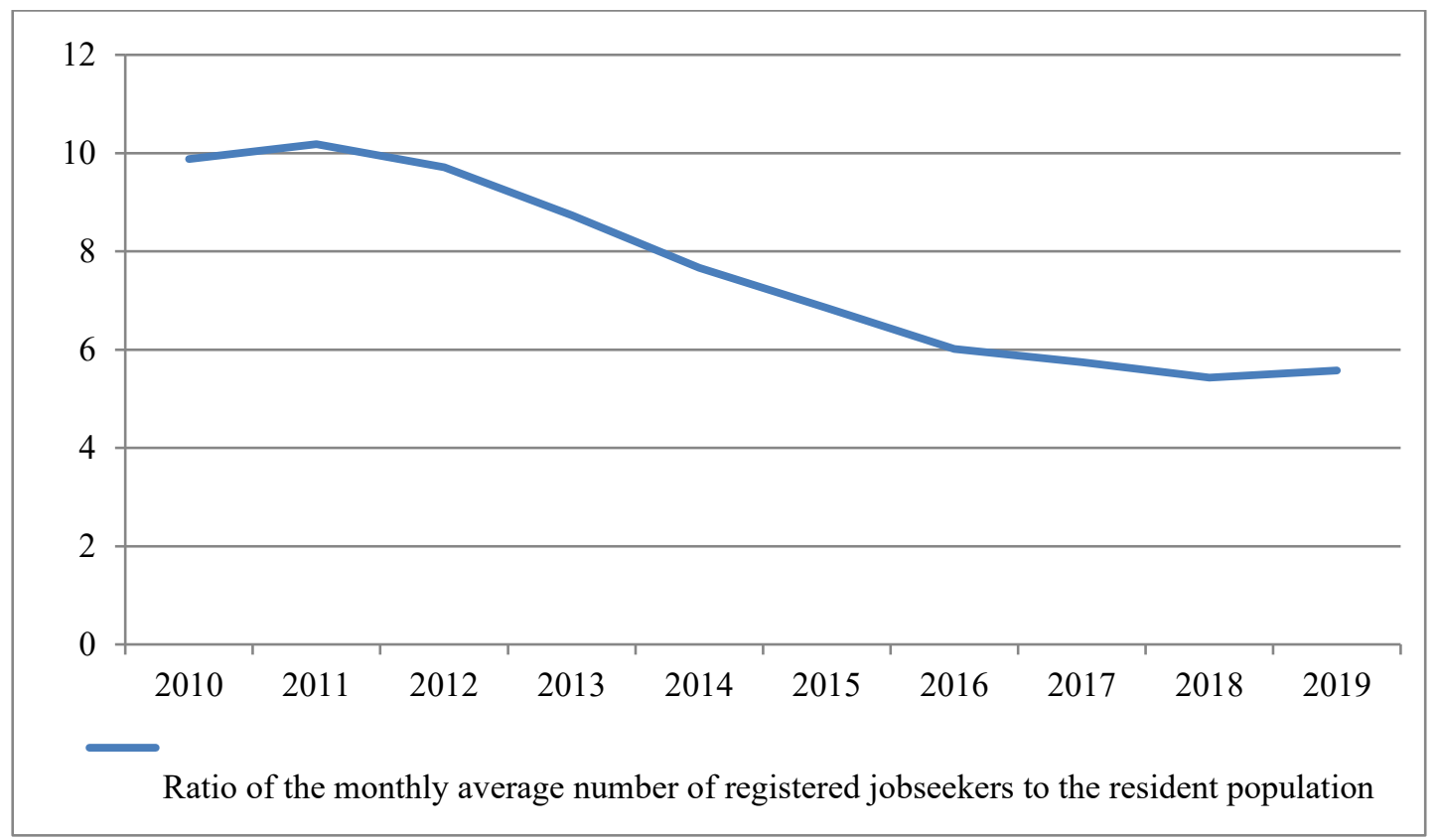

Figure 6: Ratio of the monthly average number of registered jobseekers to the resident population in Borsod-Abaúj-Zemplén County (\%)

Source: Based on own data (www.nfsz.munka.hu; www.ksh.hu)

Compared to 2010, the number of participants in adult trainig increased by $188 \%$ in BorsodAbaúj-Zemplén County. In both years studied, women participated in several trainings. The participation of men increased by $182.4 \%$, while the enrollment of women increased by $194.8 \%$ over the 10 years. In the two years analyzed, the largest change occurred in the 60-64 age group and the 65-year age group. Students appeared in these two age groups. The most dynamic increase in the number of students took place in the under-18 age group and in the 18-19 age group, with more than $300 \%$ increases in the number of students. From the point of view of the composition of the County's population, it is important to note that $11.28 \%$ of the population is over 65, which is the age group with the highest proportion in the County. The second largest age group is under 17, making up 19 percent of the County overall. (Figure 7). The age tree of Borsod-Abaúj-Zemplén County has undergone changes in the last 10 years. In the County, female residents are in the majority $(51.65 \%)$. For three age groups, the population increased in the 40-49 age group, the 60-64 age group, and the 65-year-old age group. In all age groups, which showed a larger increase, the number of men increased the most (Table 1). 
2010

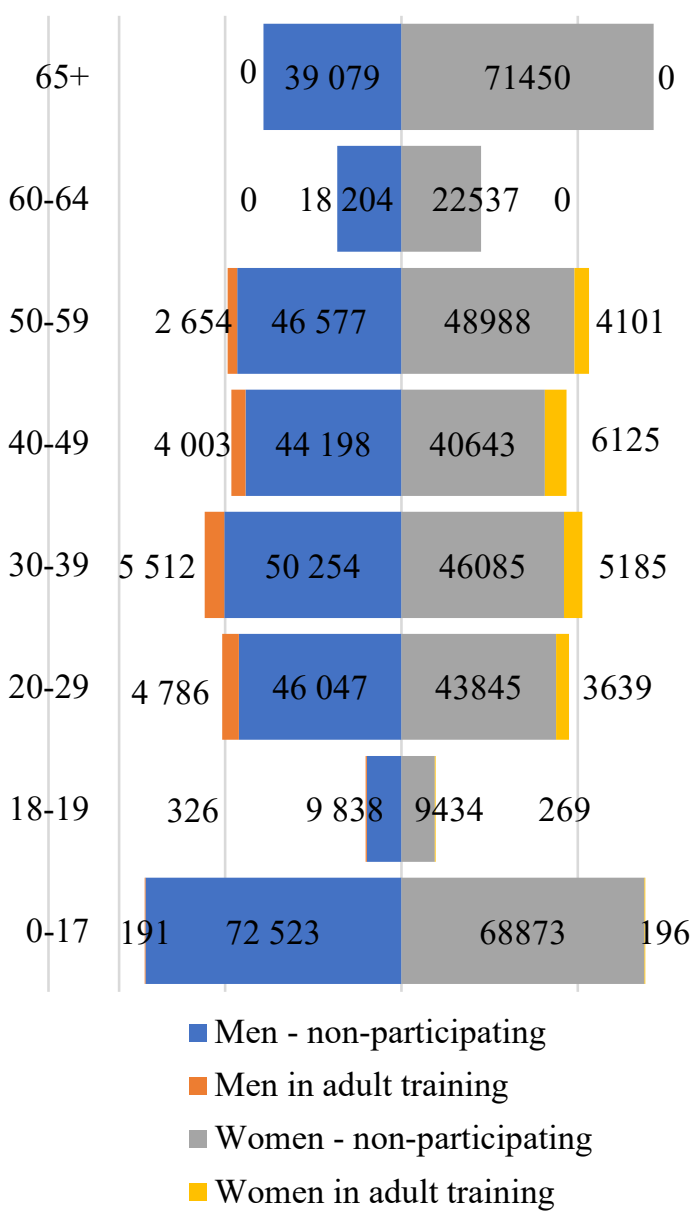

2019

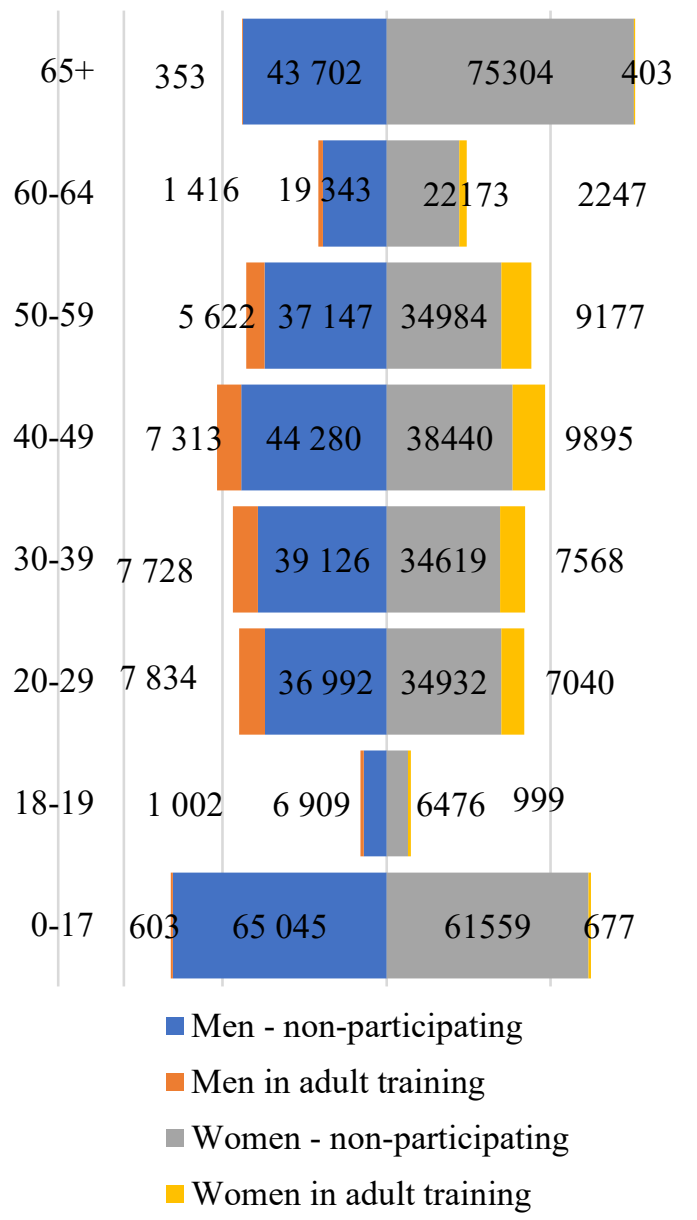

Figure 7: Borsod-Abaúj-Zemplén County age group and composition of participants in adult training (2010-2019)

Source: Based on own data (www.osap.mer.gov.hu; www.ksh.hu)

Table 1: Gender change of the resident population in Borsod-Abaúj-Zemplén County (2010-2019)

\begin{tabular}{|c|c|c|c|}
\hline \multicolumn{4}{|c|}{ Change } \\
\hline Age & Men & Women & Sum \\
\hline $0-17$ & $-9,72 \%$ & $-9,89 \%$ & $-9,80 \%$ \\
\hline $18-19$ & $-22,17 \%$ & $-22,96 \%$ & $-22,55 \%$ \\
\hline $20-29$ & $-11,82 \%$ & $-11,61 \%$ & $-11,72 \%$ \\
\hline $30-39$ & $-15,98 \%$ & $-17,72 \%$ & $-16,81 \%$ \\
\hline $40-49$ & $7,04 \%$ & $3,35 \%$ & $5,22 \%$ \\
\hline $50-59$ & $-13,13 \%$ & $-16,82 \%$ & $-15,04 \%$ \\
\hline $60-64$ & $14,04 \%$ & $8,36 \%$ & $10,89 \%$ \\
\hline $65+$ & $12,73 \%$ & $5,96 \%$ & $8,35 \%$ \\
\hline
\end{tabular}

Source: Based on own data (www.ksh.hu)

In 2010, 92 out of 358 settlements in the County had adult training courses, while in 2019 there were 194 settlements. The chief town of the county, Miskolc had an outstanding number of students in the County, in both years. In rural areas, the number of participants in adult training 
and the attainment of trainings increased (Figure 8). Education in rural settlements is usually trainings for jobseekers initiated by the Borsod-Abaúj-Zemplén County Government Office.
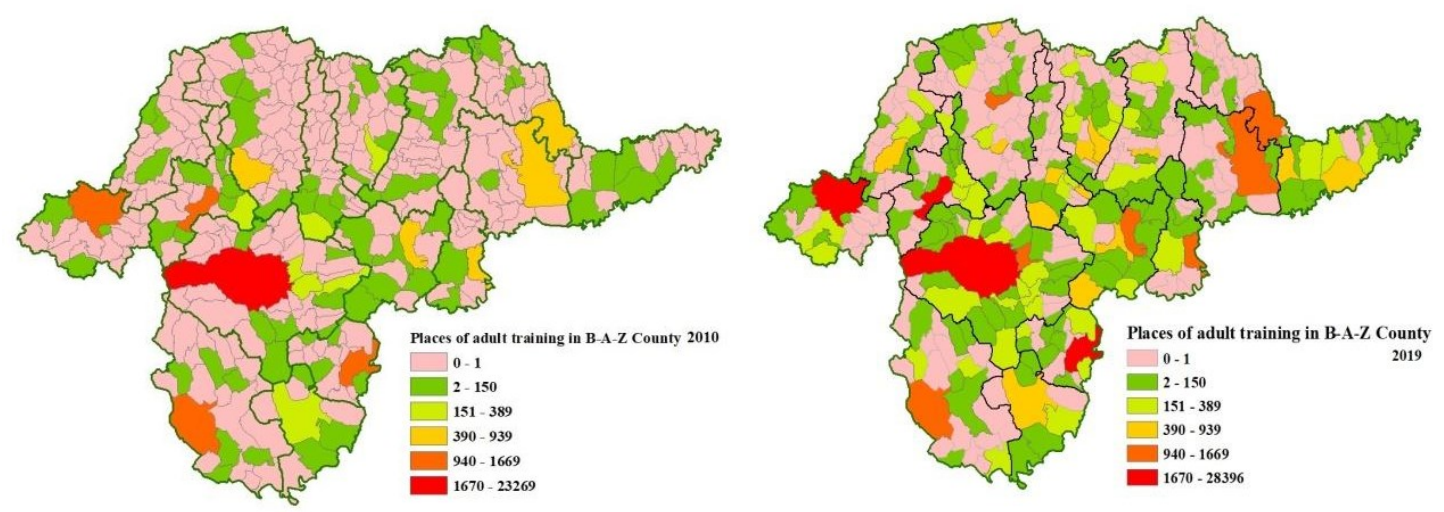

Figure 8: Adult training courses in the settlements of Borsod-Abaúj-Zemplén County $(2010,2019)$

Source: Based on own data (www.osap.mer.gov.hu)

Local Moran I statistics yielded an image of a negatively autocorrelated area. The -0.275470 Moran index $(\mathrm{z}$-score $=-1.723730$, $\mathrm{p}$-value $=0.084757)$ obtained in the spatial autocorrelation study on adult participation rates showed a negative autocorrelation. By 2019, Low-Low clusters appeared in the northern areas of Borsod-Abaúj-Zemplén County, next to the Slovak border and in the longitudinal section of the Szikszo district, from which we can conclude that adult training in these spatial units was reduced in the 10 years studied. The trainings and, at the same time, the participants in the adult training are grouped together. In peripheral areas, adult training rates declined (Figure 9).
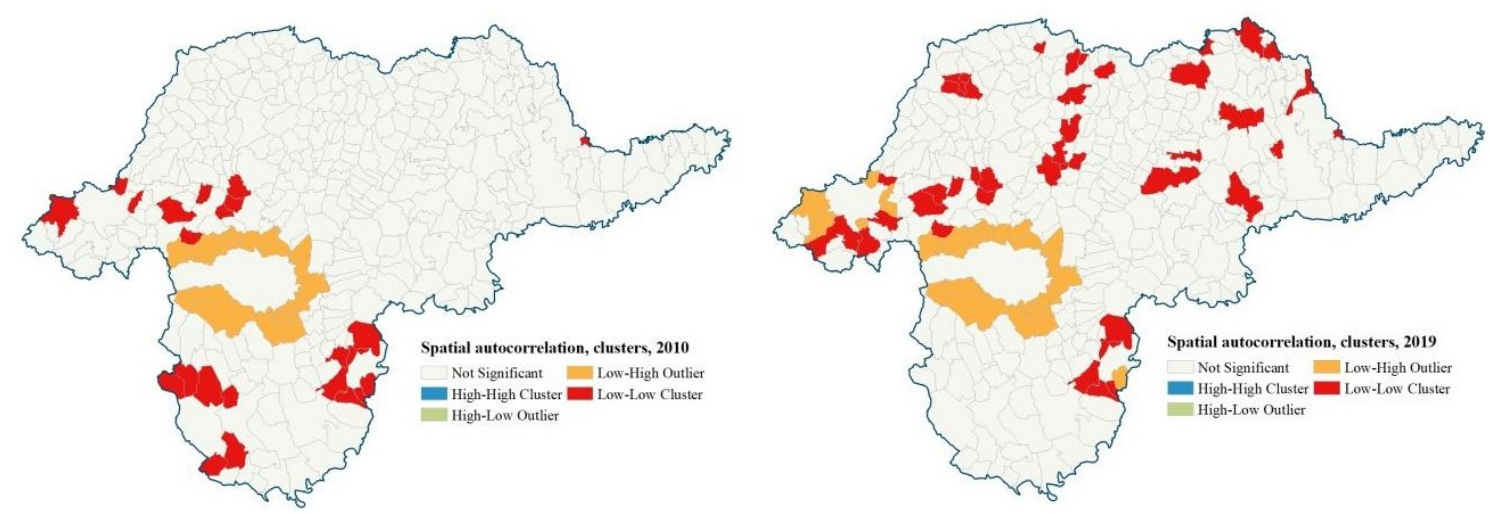

Figure 9: Spatial autocorrelation report on the territorial distribution of adult training in Borsod-Abaúj-Zemplén County (2010, 2019)

Source: Based on own data (www.osap.mer.gov.hu)

General G hotspot analytics (2010 General G: 0.305070, z-score: 2.090048, p-value: 0.036614, while by 2019 General G: 0.365366 , z-score: 1.823220 , p-value: 0.068270 data) in 2010 the Szikszó and Szerencs districts showed high Hotspot clustering, while in 2019 the Szikszó, Encs and Edelény districts, which shows that the participants in adult training its indicator shifted to the north pole of the County. It was found that the focus of adult training in the County in relation to the 100 resident population shifted to the rural areas of the County (Figure 10). 

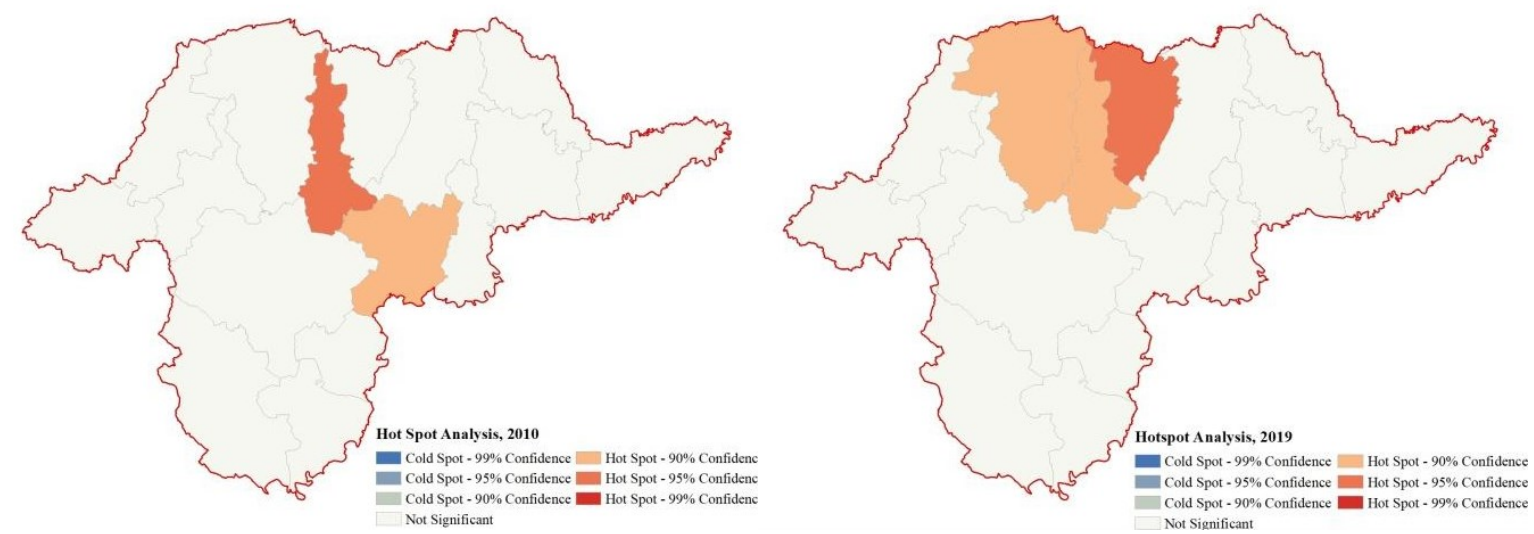

Figure 10: Hotspot analysis in the districts of Borsod-Abaúj-Zemplén County in the proportion of participants in training compared to the resident population standardized to 100 people 2010,2019

Source: Based on own data (www.osap.mer.gov.hu, www.ksh.hu)

\section{Conclusions, suggestions}

Borsod-Abaúj-Zemplén County is characterized by aging; the number of deaths far exceeds the number of live births. The population has shown a dynamic decline over the last 10 years, representing the population of a city of 49,000. In the County, emigration is very high, compared to other regions of the country. The average migration balance of the study period was $-15.6 \%$. Emigration has a positive effect on unemployment, as the absolute number of jobseekers has decreased as a result of continuous emigration.

The proportion of participants in adult training compared to the resident population shows an increasing trend. In the last two years, more than 10 percent of the population has participated in some form of adult training. Borsod-Abaúj-Zemplén County is one of the most backward counties in the country, characterized by a high unemployment rate and a low employment rate. Most people in the County participate in European Union and state-funded adult training.

The decrease in the resident population during the study period did not affect those in adult training. Despite the steady decline in the resident population, the proportion of participants has increased in the County.

In my opinion, working with multinational companies involved in the region could stop the emigration of workforce. Thanks to the joint cooperation of training institutions, the support sector and corporate decision-makers, a strong, educated, demographically stagnant County could be created in the region, where those living there have marketable qualifications and are able to adapt to economic changes.

The number of participants in adult training increased dynamically during the study period, in which those over 60 years of age also appeared in education. This is also due to the fact that the regions are aging and are retraining to secure a livelihood in order to keep their jobs.

From the spatial correlation study of the proportions of participants in adult training, it can be concluded that from 2010 to 2019 the sinter of adult training places was concentrated in the district centers, in this respect the peripheral zones of the district centers lost adult training positions. 
In the Hotspot analysis, in the years under review, from 2010 to 2019, the standardized focus of adult training participants per 100 inhabitants shifted northwards, mainly due to the training of jobseekers at the Borsod-Abaúj-Zemplén County Government Office, which was weighted by high unemployment.

\section{References}

1. Bába K. (2008): Földrajzi mobilitás, migráció. Új Ifjúsági Szemle, nyár-ősz, 117 p.

2. Csapó, B.-Molnár, Gy.-Kinyó, L. (2009): A magyar oktatási rendszer szelektivitása a nemzetközi összehasonlító vizsgálatok eredményeinek tükrében Iskolakultúra, 19 (34), pp. 3-13.

3. Dabasi-Halász Zs. - Hegyi-Kéri Á. (2015): „Fel/eltörekvő” generáció migrációja Miskolcon. Észak-magyarországi Stratégiai Füzetek 1., pp. 17-26.

4. Dunnell, K. (2009): National Statistician's article: measuring regional economic performance. $=$ Economic \& Labour Market Review 3(1), pp. 18-30.

5. Enyedi Gy. (szerk.) (1996): Társadalmi-területi egyenlőtlenségek Magyarországon. KJK, Bp., 390 p.

6. Faragó L. (2016): Társadalmi-területi egyenlőtlenségek. Tér és Társadalom 30(3), pp $118-123$.

7. Farkas É. (2013): A láthatatlan szakma. Tények és tendenciák a felnőttképzés 25 évéről. typiArt Médiamühely Kft., Pécs, pp. 185-240.

8. Földvári E. (2014): Magyarország népességének várható alakulása 2060-ig, különös tekintettel a nemzetközi vándorlásra. Demográfia. 57(4), pp. 241-269.

9. Gubacsi F. (2017): A gazdaságfejlesztés új irányai Recsk nagyközségben. In: Tánczos T. - Csugány J. (szerk.) Gazdaság- és Társadalomtudományi Kar Tudományos Diákköri Konferencia Tanulmánykötete. EKE Líceum Kiadó, Eger, pp. 128-141.

10. Gödri I. - Feleky G. A. (2013): Migrációs tervek megvalósulása egy követéses vizsgálat tükrében. Az előzetes migrációs szándék, a várakozások és a külső elvárások szerepe. Demográfia, 4., pp. 281-332.

11. Győri, T. - Járdány K. (2019): Comparsion of Hungarian labor market databases In: Egri, Z. - Krajcsovicz, M. - Molnárné Paraszt M. (szerk.) Digitization in Rural Spaces - Challenge and/or Opportunity? 3rd International Scientific Conference on Rural Development, Conference Proceedings, SZIE AGK, Szarvas, pp. 77-85.

12. Hangya, D. (2013): "Esélyegyenlőségi útmutató" Fogyatékossággal élők és megváltozott munkaképességüek esélyei és lehetőségei a felnőttképzésben “A Guide to Equal Opportunities" - Opportunities for People with Disabilities and Decreased Work Ability in Adult Education. In: Szabó Ferenc: International Conference on Vocational and Adult Education, SZTE JGYPK, Szeged, pp. 271-281

13. Híves T. (2015): Területi oktatáskutatás. Vizsgálatok az iskolázás területi folyamatairól. Doktori disszertáció. Pécsi Tudományegyetem, 216 p.

14. Kapitány B. - Pakot L. - Rohr A. - Szabó L. - Tóth G. - Vargha L., (2015): Demográfiai Fogalomtár Budapest, Magyarország: KSH Népességtudományi Kutatóintézet, 78 p. ISBN: 9789639597365

15. Kiss J. P. - Németh N. (2006): Fejlettség és egyenlőtlenségek. Magyarország megyéinek és kistérségeinek esete. Budapesti Munkagazdaságtani Füzetek, 2006/8.

16. Koncz G. - Szücs A. - Nagyné Demeter D., (2018): A gazdaság térszerkezetének változásai Észak-Magyarországon az ezredforduló után. Jelenkori Társadalmi és Gazdasági Folyamatok 13(1-2), pp. 139-149.

17. Lipták K. (2017): Települési humán potenciál vizsgálata Magyarországon. = Északmagyarországi Stratégiai Füzetek 14(2), pp. 55-64. 
18. Lux G. (2017): A külföldi működő tőke által vezérelt iparfejlődési modell és határai Közép-Európában. $=$ Tér és Társadalom 31(1), pp. 30-52.

19. Matolcsy Gy. - Csizmadia N. - Csordás L. (2007): A magyar gazdaság térszerkezeti változásai. Térbeli dimenziók, fejlődési tengelyek, övezetek. Magyar Gazdaságfejlesztési Intézet

20. Nagy E. - Timár J. - Nagy G. - Velkey G. (2015): A társadalmi-térbeli marginalizáció folyamatai a leszakadó vidéki térségekben. = Tér és Társadalom 29(1), pp. 35-52.

21. Nemes-Nagy J. (2004): Elements of regional disparities in the new regional pattern. In: Enyed Gy.-Tózsa I. (ed.) The Region. Regional development, policy, administartion and e- government. Akadémiai Publ., Bp., pp. 62-79.

22. Obádovics Cs. - Bruder E. (2011): A vidéki Magyarország területi egyenlőtlenségei különböző nézőpontokból. = Gazdaság \& Társadalom 3(2), pp. 74-92.

23. Pénzes J. (2015): A kedvezményezett térségek lehatárolásának aktuális kérdései. = Területi Statisztika 55(3), pp. 206-232.

24. Rajnai, J. (2012): Lehet másképp?!: Avagy pedagógiai alternatívák a hátrányos helyzetű roma fiatalok nevelésében. Új Pedagógiai Szemle 62(11-12), pp. 54-75.

25. Rédei M. (2006): Demográfiai ismeretek. Budapest, 6. p.

26. Rolleston, C. - James, Z. (2015): After access: Divergent learning profiles in Vietnam and India Prospects 45 (3), pp. 285-303. https://doi.org/10.1007/s11125-015-9361-2

27. Sucharita, V. (2014): Negotiating between Family, Peers and School. Understanding the World of Government School and Private School Students Compare 44 (3): 379393. https://doi.org/10.1080/03057925.2013.792671

28. Szücs A. (2014): A residential satisfaction examination in the micro region of Gyöngyös. = Journal of Central European Green Innovation 2(4), pp. 151-162.

29. Tésits, R. - Alpek, B. L. (2013): A képzettség, mint területi differenciáló faktor a leghátrányosabb helyzetü álláskeresők körében. Szakképzési Szemle 29(1), pp. 21-33. 